\title{
DISEMINASI PENGGUNAAN OVAPRIM UNTUK MEMPERCEPAT PEMIJAHAN IKAN MAS DI DESA SUKAMAHI DAN SUKAGALIH KECAMATAN SUKARATU KABUPATEN TASIKMALAYA PROVINSI JAWA BARAT
}

Yuatiati, A., Herawati, T. dan Nurhayati, A. E-mail: atikah.nurhayati@unpad.ac.id

\begin{abstract}
ABSTRAK
Ikan Mas (Cyprinuscarpio) merupakan salah satu jenis ikan air tawar yang banyak di budidayakan di Kabupaten Tasikmalaya. Budidaya ikan mas dapat dilakukan secara semi intensif dan intensif dengan memperhitungkan nilai ekonomi.Pemijahan ikan secara intensif, yaitu pemijahan ikan yang terjadi dengan memberikan rangsangan hormon untuk mempercepat kematangan gonad serta proses ovulasinya dilakukan secara buatan dengan teknik stripping atau pengurutan. Tehnik pemijahan ikan mas menggunakan hormon ovaprim. Intensifikasi budidaya perikanan harus memperhatikan ketersediaan benih secara kontinyu dengan kualitas yang bagus dengan dukungan teknologi tepat guna.Penggunaan teknologi tepat guna diperlukan oleh masyarakat, khususnya tehnik pemijahan buatan untuk ikan mas dengan menggunakan hormon ovaprim. Pemijahan ikan secara intensif, yaitu pemijahan ikan yang terjadi dengan ovaprim. Maksud dari pengabdian ini untuk menganalisis peluang usaha budidaya ikan mas dan teknik pemijahan ikan mas dengan menggunakan ovaprim dalam rangka meningkatkan pendapatan masyarakat. Berdasarkan hasil evaluasi dan monitoring selama kegiatan pengabdian kepada masyarakat yang berlangsung secara simultan dengan mengggunakan metode partisipasi masyarakat, demonstrasi lapangan(demplot) kolam pemijahan dan faktor pendorong kegiatan pengabdian kepada masyarakat ini yaitu :(1) ketersediaan sumber daya alam diantaranya lahan yang telah dibuat kolam untuk perikanan; (2) sumberdaya air; (3) ketersediaan pakan alami ;(4) ketersediaan tenaga kerja keluarga; (5) peluang pasar perikanan budidaya air tawar. Kegiatan ini mampu memberikan motovasi kepada masyarakat untuk pengembangan komoditas perikanan air tawar, sehingga mampu meningkatkan kesejahteraan keluarga.
\end{abstract}

Kata Kunci : ikan mas, pemijahan, ovaprim, stripping

\section{ABSTRACT}

Goldfish (Cyprinuscarpio) is one freshwater fish species are widely cultivated in Tasikmalay a regency. Cultivation of carp can be done in semi-intensive and intensive by calculating the value ekonomi.Pemijahan intensive fish, that spawning occurs by providing a stimulus to accelerate the maturity of gonadal hormones and ovulation process is done artificially by stripping technique or pengurutan.Tehnik spawning carp using ovaprim hormone. Intensification of aquaculture must consider continuous availability of seeds with good quality with the right technology support guna.Penggunaan appropriate technology needed by the community, especially the artificial spawning techniques for carp using ovaprim hormone. Spawning fish intensively, ie spawning happens with ovaprim. The intent of this devotion to analyze the opportunities cultivation of carp and carp spawning techniques using ovaprim in order to increase people's income. Based on the evaluation and monitoring for community service activities that took place simultaneously with the use traditional methods of community participation, demonstration field (plots) spawning ponds and the factors driving community service activities are: (1) the availability of natural resources including land that has been made pond for fisheries; (2) water resources; (3) the availability of natural feed; (4) the availability of family labor; (5) market opportunities freshwater aquaculture. This activity is able to provide motovasi to the community to the development of freshwater fishery commodities, so as to improve the welfare of the family.

Keywords: goldfish, spawning, ovaprim, stripping

\section{PENDAHULUAN}

Masyarakat yang berada di Desa Sukamahi dan Sukagalih Kecamatan Sukaratu Kabupaten Tasikmalaya pada umumnya telah mengenal ikan mas (Cyprinus carpio, L) dan bisa di konsumsi untuk memenuhi kebutuhan protein bagi manusia. Pemenuhan permintaan ikan mas, tentu harus memperhatikan aspek budidaya. Budidaya ikan mas memerlukan input produksi berupa benih, pakan, tenaga kerja, ketersediaan lahan untuk pembuatan kolam. Input produksi berupa benih ikan memiliki keterbatasan secara alamiah, karena bersifat musiman yang tersedia pada saat musim penghujan, sedangkan pada musim kemarau stok benih secara alamiah mengalami penurunan, sehingga diperlukan ketersediaan benih pada musim kemarau, salah satunya dengan cara pemijahan buatan.

Ketersediaan benih bukan hanya dalam bentuk jumlah namun kualitas benih itu sendiri yang akan menentukan pertumbuhan ikan mas yang dibudidayakan. Budidaya ikan mas dapat dilakukan secara semi intensif dan intensif dengan memperhitungkan nilai ekonomi. Analisis ekonomi dilakukan untuk menilai kelayakan usaha budidaya ikan mas. Intensifikasi budidaya perikanan harus memperhatikan ketersediaan benih secara kontinyu dengan kualitas yang bagus dengan dukungan teknologi tepat guna. Penggunaan teknologi tepat guna diperlukan oleh masyarakat, khususnya tehnik pemijahan buatan untuk ikan mas. Penggunaan alat yang mudah didapatkan oleh masyarakat dengan harga yang terjangkau. Pengetahuan baru yang diperoleh oleh masyarakat akan diproses melalui tahapan adopsi inovasi. Adanya keberhasilan penemuan ekstrak hormon ovaprim dapat memacu terjadinya peningkatan proses pemijahan pada ikan dengan kuantitas dan kualitas yang tepat.Kegiatan reproduksi pada setiap jenis hewan air berbeda-beda, tergantung kondisi lingkungnya (Fujaya, 2004).

Ikan Mas (Cyprinuscarpio) merupakan salah satu jenis ikan air tawar yang banyak dibudidayakan di sebagian besar wilayah Indonesia, dikarenakan jenis ikan ini banyak disukai oleh masyarakat. Asal 
usul ikan mas berasal dari Cina dan Rusia. Dari negeri asalnya inilah ikan mas menyebar ke daerah Eropa, Asia Timur dan Asia Selatan sekitar abad pertengahan. Di daerah baru ini, perkembangan ikan mas semakin popular terutama dalam teknik pemeliharaan dan perkembang biakannya. Di Indonesia sendiri perkembangan budidaya ikan mas terjadi sejak pertengahan abad ke-19 (Andrianto, 2005). Klasifikasi ikan mas adalah sebagai berikut:

Kelas: Osteichthyes

Anak kelas: Actinopterygii

Bangsa: Cypriniformes

Suku: Cyprinidae

Marga: Cyprinus

Jenis: Cyprinus carpio L.

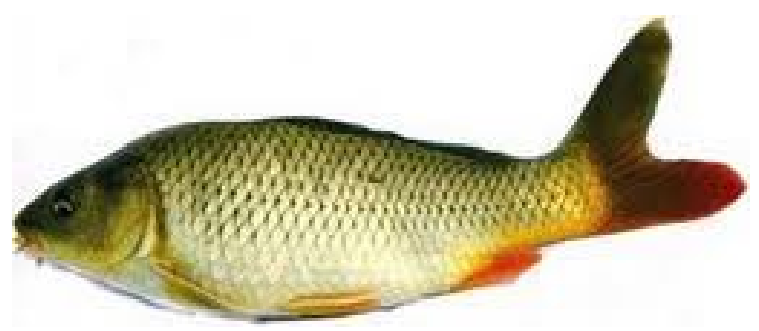

Gambar 1. Ikan Mas (Cyprinus carpio L)

Ikan mas mempunyai bentuk tubuh agak memanjang dan memipih tegak (compressed). Mulut terletak di ujung tengah (terminal) dan dapat disembulkan (protaktil). Bagian anterior mulut terdapat dua pasang sungut berukuran pendek. Secara umum, hampir seluruh tubuh ikan mas ditutupi sisik dan hanya sebagian kecil saja yang tubuhnya tidak ditutupi sisik. Sisik ikan mas berukuran relatif besar dan digolongkan dalam tipe sisik sikloid berwarna hijau, biru, merah, kuning keemasan atau kombinasi dari warna-warna tersebut sesuai dengan rasnya. Ikan mas memiliki banyak stain atau ras, perbedaan sifat dari ras disebabkan oleh adanya interaksi antara genotipe dan lingkungan kolam, musim dan cara pemeliharaan hal ini dapat diidentifikasi dari bentuk fisik dan warnanya seperti ikan mas Majalaya, ikan mas punteun, ikan mas Si Nyonya, ikan mas Taiwan dan ikan mas Koi.

\section{SUMBERINSPIRASI}

Lahan pertanian dengan sistem pengairan yang memadai memudahkan untuk usaha budidaya perikanan air tawar. Namun masih ditemukan lahan marginal yang tidak produktif belum dimanfaatkan secara optimal oleh warga setempat, khususnya di Desa Sukagalih dan Sukamahi yang berada di Kecamatan Sukaratu Kabupaten Tasikmalaya. Kondisi ini mendorong dibangkitkannya pemanfaatan lahan marginal, khususnya lahan pekarangan yang ada di Desa Sukagalih dan Sukamahi dimanfaatkan untuk budidaya perikanan air tawar, untuk menopang pasokan sentra produksi ikan air tawar di Kabupaten Tasikmalaya.

\section{METODE}

Proses penyampaian informasi melalui metode partisipasi diharapakan khalayak sasaran mampu mengadopsi pesan yang disampaikan melalui proses kognitif, afektif dan psikomotorik. Ada 5 tahap dalam mengadopsi suatu inovasi yaitu sadar (awreness), minat (interest), menilai (evaluation), mencoba (trial) dan adopsi (adoption). Tahap sadar: sasaran telah mengetahui informasi mengenai budidaya ikan mas. Tahap minat: sasaran mencari informasi atau keterangan lebih lanjut mengenai informasi budidaya ikan mas tersebut. Tahap menilai: khalayak sasaran sudah menilai dengan cara value/bandingkan inovasi terhadap keadaan khalayak sasaran pada saat itu dan di masa yang akan datang serta menentukan apakah petani dan pembudi daya khalayak sasaran mencoba inovasi atau tidak. Tahap mencoba: khalayak sasaran sudah mencoba meskipun dalam skala kecil untuk menentukan angka dan kesesuaian inovasi atau tidak. Tahap adopsi/menerapkan: khalayak sasaran sudah meyakini kebenaran inovasi dan inovasi tersebut dirasa bermanfaat baginya. Pada tahap ini petani sasaran menerapkan dalam jumlah/skala yang lebih besar.

Metode penyuluhan yang dilakukan pada diseminasi penggunaan ovaprim untuk mempercepat pemijahan ikan mas, menggunakan beberapa metode yaitu sebagai berikut: (a) demonstrasi cara adalah teknik penyuluhan perikanan berupa kegiatan untuk memperlihatkan secara nyata tentang cara penerapan teknologi perikanan yang telah terbukti menguntungkan bagi pelaku utama dan/atau pelaku usaha perikanan, khususnya tenik pengguna anovaprim; (b) temu wicara adalah metode penyuluhan perikanan berupa kegiatan pertemuan antara pelaku utama yaitu khalayak sasaran dengan pemberi materi untuk bertukar informasi mengenai program pemerintah khususnya pemda Jabar dalam pembangunan perikanan, serta antisipasi dan peran serta pelaku utama atau pelaku usaha dalam pembangunan perikanan; (c) temu teknis adalah kegiatan pertemuan berkala antara pemateri dengan tim yaitu dosen pendamping lapangan (DPL) beserta tim PKMTematik untuk meningkatkan kompetensi pembudidaya perikanan; (d) temu lapang adalah pertemuan di lapangan sebagai tindak lanjut demonstrasi cara/demonstrasi hasil/ uji coba lapang. Agar penyelenggaraan temu lapang dapat berjalan dengan baik, maka harus diperhatikan prinsip-prinsip penyelenggaraannya adalah: 1) adanya kesenjangan teknologi; dan 2) teknologi yang ada di lapangan harus mempunyai kinerja yang lebih baik dari sebelumnya, dapat memecahkan masalah dan sesuai dengan kebutuhan pelaku utama yaitu pembudidaya ikan air tawar khususnya ikan mas.

\section{KARYA UTAMA}

Karya utama dari kegiatan PKM-Tematik yaitu: (1) aspek teknologi penerapan IPTEK melalui proses adopsi inovasi penggunaan ovaprim untuk mempercepat pemijahan ikan mas dan demplot kolam percobaan; (2) aspek manajemen yaitu penerapan managemen yang baik dalam rangka efektivitas dan efisiensi produksi perikanan budidaya air tawar khususnya ikan mas ; (3) aspek basis ekonomi yaitu pemanfaatan sumberdaya ekonomi lokal yang meliputi antara lain, informasi pasar, potensi sumberdaya yang diperlukan untuk pengembangan usaha dan peningkatan kesejahteraan; (4) aspek ekologis, pemahaman dan kesadaran akan penting kelestarian SDA sehingga kegiatan usaha bisa berkelanjutan dan tidak merugikan lingkungan; (5) 
aspek social budaya, pengembangan kondisi social dan kesadaran cultural untuk meningkatkan kesejahteraan dengan mempertimbangkan adat budaya setempat.

\section{ULASAN KARYA}

Pemijahan adalah proses perkawinan antara ikan jantan dan ikan betina yang mengeluarkan sel telur dari betina, sel sperma dari jantan dan terjadi di luar tubuh ikan (eksternal). Dalam budidaya ikan, teknik pemijahan ikan dapat dilakukan dengan tiga macam cara, yaitu: (1) Pemijahan ikan secara alami, yaitu pemijahan ikan tanpa campur tangan manusia, terjadi secara alamiah (tanpa pemberian rangsangan hormon); (2) Pemijahan secara semi intensif, yaitu pemijahan ikan yang terjadi dengan memberikan rangsangan hormon untuk mempercepat kematangan gonad, tetapi proses ovulasinya terjadi secara alamiah di kolam; (3) Pemijahan ikan secara intensif, yaitu pemijahan ikan yang terjadi dengan memberikan rangsangan hormon untuk mempercepat kematangan gonad serta proses ovulasinya dilakukan secara buatan dengan teknik stripping atau pengurutan (Gusrina, 2008).

Tehnik pemijahan ikan mas menggunakan hormon ovaprim. Hormon merupakan suatu senyawa yang ekskresikan oleh kelenjar endokrin, dimana kelenjar endokrin adalah kelenjar buntu yang tidak memiliki saluran (Zairin, 2002). Kelenjar endokrin pada ikan menurut Lagler et al. (1962) dalam Gusrina (2008) terdapat beberapa organ antara lain pituitari, pineal, thymus, jaringan ginjal, jaringan kromaffin, interregnal tissue, corpuscles of stannus, thyroid, ultibranchial, pancreatic islets, intestinal tissue, intestitial tissue of gonads dan urohypophysis. Teknik penyuntikan hormon pada ikan ada 3 yaitu intra muscular (penyuntikan kedala motot), intra peritorial (penyuntikan pada rongga perut), dan intracranial (penyuntikan di kepala) (Susanto, 1999).

\section{MANFAAT}

Manfaat yang diperoleh dari kegiatan diseminasi penggunaan ovaprim untuk mempercepat pemijahan ikan mas meningkatkan pengetahuan kepada masyaraat mengenai tehnik pemijahan budidaya ikan air tawar secara buatan dengan menggunakan hormon ovaprim.

\section{SIMPULAN}

Berdasarkan hasil kegiatan PKM-Tematik di lapangan dapat disimpulkan sebagai berikut: (1) Tingkat partisipasi masyarakat terhadap kegiatan KKNMPKM Tematik memiliki antusias yang tinggi di kedua desa yaitu Desa Sukamahi dan Sukagalih Kecamatan Sukaratu Kabupaten Tasikmalaya; (2) Proses adopsi inovasi penggunaan ovaprim untuk mempercepat pemijahan ikan mas dilakukan dengan metode partisipasi melalui temu wicara, diskusi dan demontrasi lapangan melalui kolam percobaan yang dilakukan di Desa Sukagalih dan Sukamahi; (3) Berdasarkan hasil evaluasi dan monitoring bahwa masyarakat Desa Sukagalih lebih responsif terhadap kegiatan PKMTematik melalui kelompok pembudidaya ikan, dalam menerapkan penggunaan ovaprim untuk pemijahan ikan mas secara buatan.

\section{DAFTAR PUSTAKA}

Djuhanda dan Tatang. 1981. Dunia Ikan. Bandung: Armico.

Effendie, M.I. 1979. Biologi Perikanan Cetakan I. Bogor: Yayasan Dewi Sri.

Fujaya, Y. 2004. Fisiologi Ikan, Dasar Pengembangan Teknologi Perikanan. Jakarta: Penerbit Rineka Cipta

Gusrina. 2008. Budidaya Ikan untuk SMK. Direktorat Pembinaan Sekolah Menengah Kejuruan Departemen Pendidikan Nasional, Jakarta.

Susanto, H. 1999. Teknik Kawin Suntik Ikan Ekonomis. Jakarta: Penebar Swadaya. 